\title{
Unusual presentation of central pontine myelinolysis
}

\author{
Dr Jayadave Shakher. Consultant Diabetologist and Endocrinologist \\ Birmingham Heartlands Hospital, Heart of England NHS Trust, UK
}

\section{Introduction}

Central pontine myelinolysis, CPM classically occurs in alcoholics, malnourished and elderly, few days following rapid correction of hyponatraemia resulting in permanent neurological squeal. We described two cases of CPM occurring in alcoholics after 3 weeks of hospital admission with complete recovery of gross neurological signs.

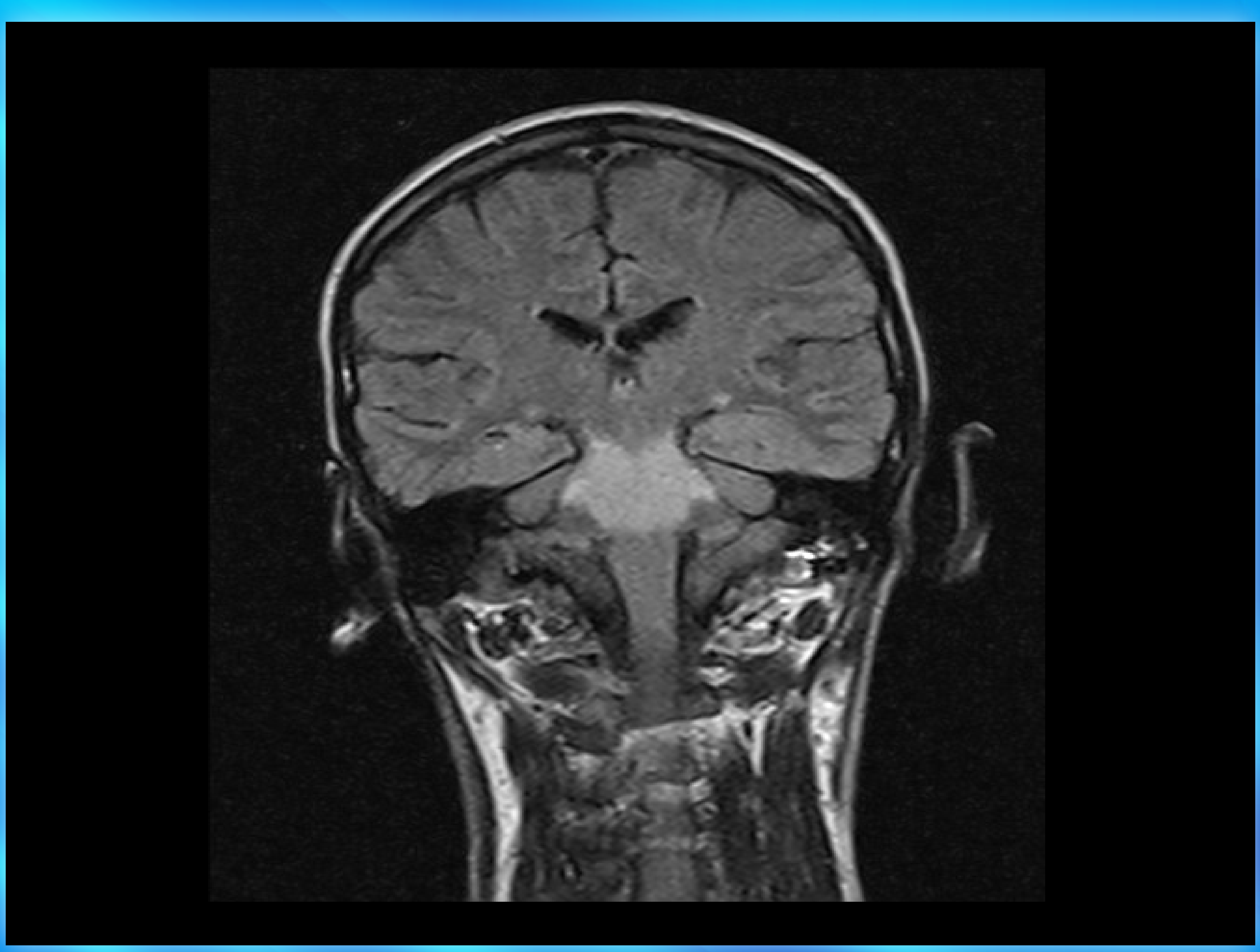

\section{Case 1}

24 year old male, known alcoholic, was admitted with left hemiplegia and features of bulbar and pseudobulbar palsy with dysphagia, dysarthria and emotional lability. Admission biochemistry including serum sodium was normal apart from mildly elevated liver enzymes. No clinical evidence of infection or vasculitis with normal FBC, CRP and ESR. MRI Brain showed evidence of pontine and extrapontine myelinolysis. Previous clinical records showed patient was admitted 4 weeks ago with alcohol intoxication with rapid correction of hyponatraemia with intravenous $0.9 \% \mathrm{NaCl}$ and did not manifest any neurological deficits on discharge. He was transferred to rehabilitation unit requiring all assistance with activities of daily living including nasogatric feed. He made a complete recovery after 6 months leading an independent life.

\section{Case 2}

55 year old alcoholic admitted with intoxication and received intravenous $0.9 \% \mathrm{NaCl}$ with rapid correction of sodium and developed delayed presentation of CPM with swallowing and speech difficulties and became wheel chair bound. MRI Brain demonstrated typical picture of CPM. He made a complete recovery after 3 months.

\section{Discussion}

CPM is a non-inflammatory demyelinating condition affecting central pons and in 10\% extrapontine sites typically involving myelin with sparing of neurons and axons. The postulated mechanism is due to rapid osmotic fluctuating from overzealous correction of sodium resulting in damage to endothelial cells with release of some myelinotoxic factors. The prognosis is poor with death or permanent neurological damage but both the cases described made complete recovery.

\section{Recommendation}

Gradual correction of serum sodium no more than $8 \mathrm{mmol} / \mathrm{L}$ in 24 hours in high-risk group.

\section{References}

Karp BI, Laureno R. Pontine and extrapontine myelinolysis: a neurologic disorder following rapid correction of hyponatremia. Medicine (Baltimore)

Nov 1993;72(6):359-73.

Martin RJ. Central pontine and extrapontine myelinolysis: the osmotic demyelination syndromes. J Neuro/Neurosurg Psychiatry. Sep 2004;75

Suppl 3:ifi22-8.

Kumar S, Fowler M, Gonzalez-Toledo E, Jaffe SL. Central pontine myelinolysis, an update. Neurol Res. Apr 2006;28(3):360-6. 